\title{
3. THE SAPROPEL THEME OF LEG 160
}

\author{
Kay-Christian Emeis ${ }^{2}$ and Tatsuhiko Sakamoto ${ }^{3}$
}

\begin{abstract}
Research on sediments recovered during Ocean Drilling Program Leg 160 has concentrated on two issues: 1) the stratigraphy of sapropel formation, and 2) the clarification of specific processes that explain sapropel origin. Progress has been made in the construction of stratigraphic composites out of sedimentary sequences from individual holes at each of the paleoceanographic sites. On the composites, initial work has resulted in the establishment of high-resolution and intermediate-resolution stratigraphies for three sites (Sites 963,964, 967); correlation of sedimentary cycles to astronomical (insolation) cycles extends the stratigraphies to Sites 969 and 966. The sapropel occurrences in the marine and land sequences over the entire Eastern Mediterranean are correlatable; with the resolution that can be obtained from isotope studies, groups of sapropels occurred simultaneously over the entire basin. In detail, however, the temporal and facies patterns of sapropel sequences differ between individual sites and depositional basins. The differences may be related to effects of water depth, diagenesis, and postdepositional tectonic attenuation of sequences. Studies on the geochemistry and facies of sapropels agree that anoxic conditions favored preservation of organic matter in sapropels, caused the enrichment of trace metals associated with sapropels, and helped preserve primary sedimentary structures. All evidence is consistent with elevated flux of organic matter and associated elements during sapropel events.
\end{abstract}

\section{INTRODUCTION}

Ocean Drilling Program (ODP) Legs 160 and 161 occupied a transect of drill sites in the Mediterranean Sea in the spring of 1995. The companion legs were designed to study the tectonic and paleoceanographic evolution of the Mediterranean Sea. The paleoceanographic aims were to recover sediment records from all basins of the Mediterranean Sea since the re-establishment of marine conditions in the Mediterranean Sea after the Miocene. The materials obtained during these campaigns have been examined by participants of the scientific parties and shore-based researchers over the last two years. Their goal was to investigate the origins of sapropels and their significance as recorders of climatic and paleoceanographic variability in the Mediterranean Sea and surrounding land masses. The main body of results assembled from Leg 160 is published in this volume.

As an introduction to the results of Leg 160, this paper summarizes the rationale for drilling the paleoceanographic transect. It outlines strategies of shipboard and shore-based research, points at some important results, and suggests research on unanswered questions remaining after two years of research.

\section{OBJECTIVES OF LEG 160}

The central objective of Ocean Drilling Program Legs 160 and 161 was to obtain complete sedimentary records of Pliocene to Holocene age from all basins of the Mediterranean Sea (Fig. 1; Emeis, Robertson, Richter, et al., 1996). The sites bracket a water depth interval of 600-4100 m today.

It was expected that successful recovery of sapropel-containing sequences along an east-west transect would permit the detailed evaluation of timing of sapropel formation between the individual basins. It was further hoped that the study of geochemical, micropale-

${ }^{1}$ Robertson, A.H.F., Emeis, K.-C., Richter, C., and Camerlenghi, A. (Eds.), 1998. Proc. ODP, Sci. Results, 160: College Station, TX (Ocean Drilling Program).

${ }^{2}$ Institut für Ostseeforschung Warnemünde, Seestrasse 15, D-18119 Warnemünde, Federal Republic of Germany. kay.emeis@io-warnemuende.de Japan. ontological, and isotopic properties of the sediments would allow the reconstruction of hydrographic conditions in the entire Mediterranean Sea over the time interval since the re-establishment of open marine conditions after the Miocene. Recovering long marine records from the vicinity of land exposures was to link known marine sapropels (restricted to the late Quaternary) to land sections. Stratigraphic studies on land exposures have in recent years yielded a wealth of stratigraphic information and have shown the usefulness of cyclostratigraphy. Extending the high-resolution time scale established on land to marine sediments across the entire eastern and western Mediterranean was considered to be a promising basis for an evaluation of the paleoceanographic, paleochemical, and paleontological reconstruction of the basin (Fig. 1A, 1B).

Among the key locations drilled for paleoceanographic objectives during Leg 160 are Eratosthenes Seamount Sites 966 and 967. They are today located in an area bounding the formation area of intermediate water masses and are at the same time recorders of fresh water signals originating from the eastern and southern watershed of the Mediterranean Sea. Site 963 in the Strait of Sicily monitored the seaway through which water mass exchange between the eastern and western basins occurred. Because sedimentation rates here were higher than expected and because safety considerations precluded deeper drilling, the record at Site 963 only covers the last 1.6 Ma. Furthermore, Leg 160 occupied sites for monitoring changes in water mass character in middle-water formation (on the Mediterranean Ridge, Site 969) and deep-water formation of the Eastern Mediterranean (in the Ionian Basin, Sites 964 and 972; Fig. 1B).

Each site was drilled in multiple holes that were spaced tens to hundreds of meters apart. There were two reasons for doing this.

1. To ensure highest-quality information on the depositional environment during sapropel formation, sampling density in the sapropel layers (as well as in the "normal" sediments immediately below and above the sapropels) had to be on the scale of centimeters to millimeters. Such high-sampling resolutions were considered essential for determining the factors that led to the formation of the sapropels and helped in maintaining an environment favorable for the formation of sapropels over time scales of centuries or millennia. Multiple holes were drilled using the advanced hydraulic piston corer (APC) at all

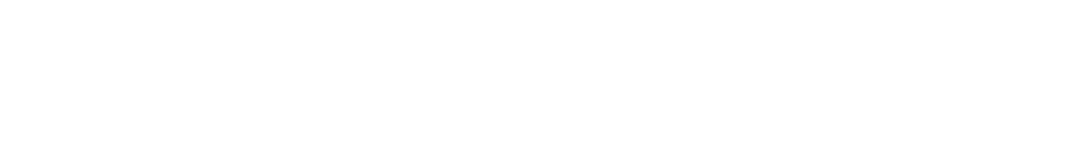


W
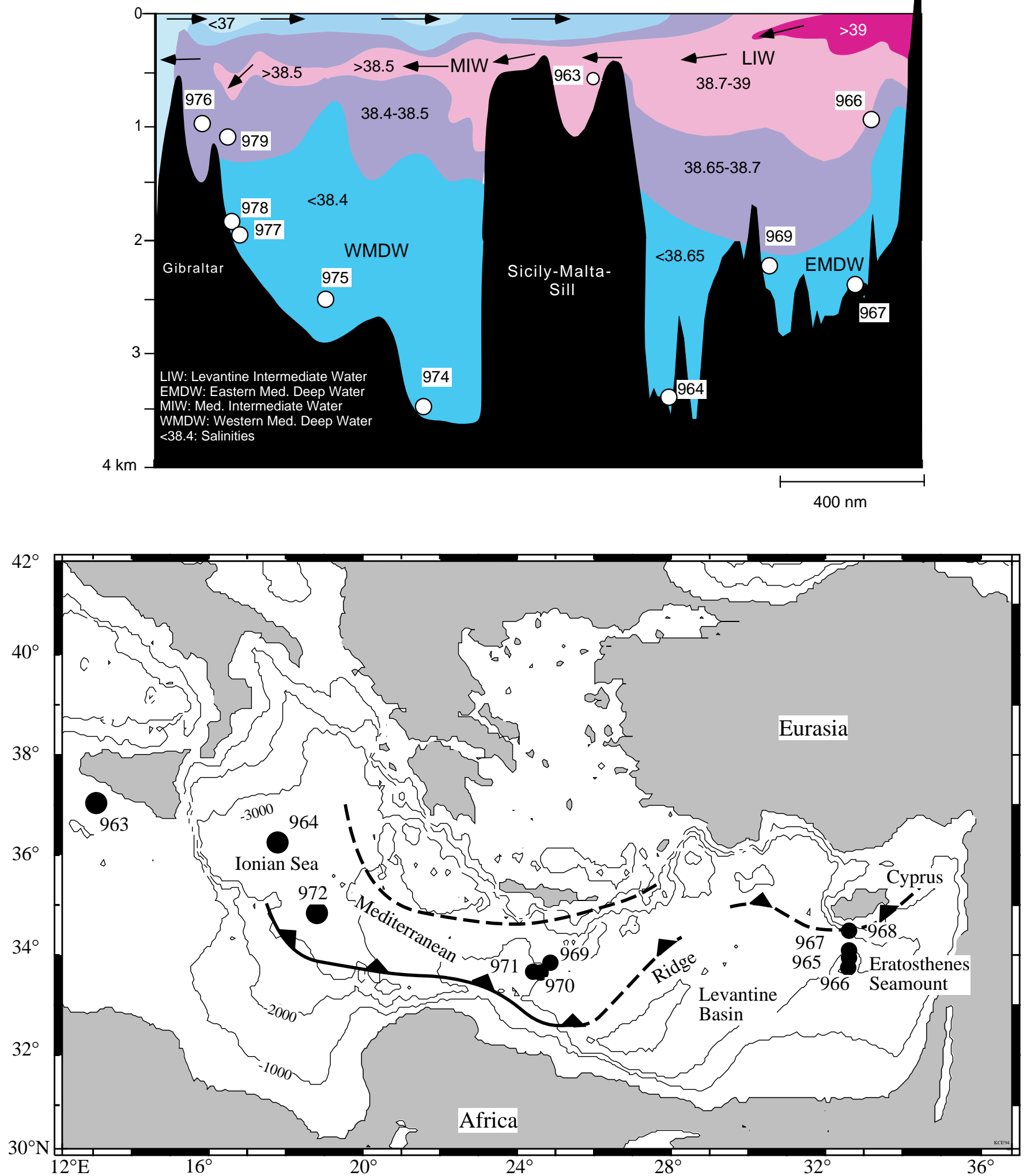

Figure 1. Top: Hydrographic section through the Mediterranean Sea (after Wüst [1961] and Vergnaud-Grazzini et al. [1977]) giving the major water masses and their salinities. Locations of sapropel sites drilled during Legs 160 and 161 are plotted at their water depth level. Bottom: Location of sites in the Eastern Mediterranean. 
paleoceanographic sites to provide sufficient material to allow intense sampling at the proposed eastern Mediterranean sites where sapropels occur.

2. The multiple recovery was to ensure that complete records were cored and to create composite records from continuously logged cores.

Although most of the chosen sites met the criteria of continuous sedimentation and high temporal resolution, the best stratigraphic information comes from Site 967, which had been selected to answer primarily tectonic questions (Kroon et al., Chap. 14, this volume). On the other hand, Site 969, which is on the Mediterranean Ridge in relatively shallow water, was to serve as the central site in the transect and record water mass properties at the interface between the Levantine and Ionian Basins. Here, the correlation between individual holes proved to be difficult because the sequences varied significantly between locations only tens of meters apart (Emeis, Robertson, Richter, et al., 1996). However, first attempts at stratigraphic intercorrelation based on continuously measured sediment color (Sakamoto et al., Chap. 4, this volume) suggest that an exceptionally well-developed sequence of sapropels has been obtained from this site. Ongoing analyses of isotope stratigraphy and sediment geochemistry on material from Site 969 will link the records of the Ionian Basin (Site 964) to those from the Levantine Basin (Sites 966 and 967).

\section{PROGRESS IN SHORE-BASED STUDIES SINCE LEG 160}

Postcruise work of the Leg 160 scientific party concentrated on two main areas of research in the last two years. The first area was concerned with establishing a stratigraphy of high temporal resolution, which is a prerequisite for establishing the patterns of sapropel occurrences through time in each of the individual locations. The second area was concerned with comparing paleoenvironmental proxy indicators in isochronous intervals in different sectors of the basin and in different depositional settings (e.g., water depth and proximity to deep-water formation areas). The scientists needed time-equivalent sapropels from different locations to compare their properties. One aspect of this second area was to correlate land sequences (elevated by tectonic activity over the last million years) and marine sequences to combine these two types of records. By comparing the sapropel properties, facies, and occurrence patterns from the widest possible variety of depositional environments, it was hoped that changes introduced by regional differences in the depositional environment, diagenesis after deposition, and tectonic uplift and weathering could be discerned.

\section{Stratigraphy}

A crucial effort in establishing high-resolution stratigraphies was the construction of composite sedimentary sections for each site. Sakamoto et al. (Chap. 4, this volume) pieced together complete and expanded sequences from records of continuous color reflectance measurements (one measurement for each $2 \mathrm{~cm}$ ) and from digitized core photos of all holes at each site. The results show that the drilling records from individual holes inevitably miss portions of the sedimentary sequences and, on average, recover only $90 \%$ of the complete sequence. Artificial coring gaps of up to $8 \mathrm{~m}$ length are exacerbated by tectonic disturbance and diagenetic erasure of some sedimentary features in the recovered sequences from all paleoceanographic sites. The product of the splicing effort prepared by Sakamoto et al. (Chap. 4, this volume) rectified the shortcomings of individual drilled sequences, correlated the sequences from individual holes at each site with each other on a scale of centimeters, and created the spine for optimal sampling schemes for postcruise sam- pling. The sapropels and their oxidized remains (the so-called ghosts) have specific optical properties that have been measured during Leg 160 in high resolution. The composite high-resolution records of lightness and color spliced together from individual holes clearly show the presence of sapropels and bundles of sapropels along the stratigraphic sequence.

The stratigraphies of the sedimentary sequences were established using micropaleontology (Staerker, Chap. 7, this volume; di Stefano, Chap. 8, this volume; Lourens et al., Chap. 15, this volume), paleomagnetism (Richter et al., Chap. 5, this volume; Stoner et al., Chap. 6 , this volume), and stable oxygen isotope composition of planktonic foraminifers (Howell et al., Chap. 13, this volume; Kroon et al., Chap. 14, this volume). All contributions offer very mature stratigraphic control for Sites 963, 964, 967, and 969, because they employ the technique of cyclostratigraphic tuning to the astronomical insolation record. Age control for each point along the composite sequences is better than a few thousand years, because the available biochronologies and isotope stratigraphies have been used as checks to verify the much more detailed stratigraphic possibilities afforded by cyclostratigraphy calibrated to astronomical cycles. Figure 2 depicts the occurrence of sapropels through time (Sakamoto et al., 1997) in the composite sequences of the four paleoceanographic Sites 967, 966, 969 , and 964. The ages assigned to the beds have been derived from stable isotope stratigraphy (Howell et al., Chap. 13, this volume; Kroon et al., Chap. 14, this volume) and from cyclostratigraphy (Lourens et al, Chap. 15, this volume). More comprehensive stratigraphic summaries are being prepared, and additional data are forthcoming for Site 969.

The major result of the stratigraphic studies is that first-order patterns of sapropels and their occurrence through time in land and sea records are correlatable from the lowermost Pliocene to the Holocene (Lourens et al., Chap. 15, this volume; Sprovieri et al., Chap. 12, this volume; Kroon et al., Chap. 14, this volume). When examining the patterns of sapropel occurrence in Figure 2 closely, differences are also obvious in the patterns of sapropels deposited at different sites. Site 967 in the deep Levantine Basin, for example, contains the highest number of sapropels and considerably more than neighboring Site 966, which is on Eratosthenes Seamount. The so-called "Gaussbundle" of sapropels (a prominent group of sapropels that is dated from 3.2 to $2.8 \mathrm{Ma}$ ) contains from 10 individual sapropels at Site 964 to 16 individual sapropels at Site 966 . For the period from 2 to 1.2 Ma, Lourens et al. (Chap. 15, this volume) show an almost complete correspondence of sapropel and ghost patterns between time-equivalent sequences from marine sediments exposed now in land sections of Vrica and Singa (Sicily), Site 969 (Mediterranean Ridge), and Site 967 (Levantine Basin). On the other hand, Sprovieri et al. (Chap. 12, this volume) compare the records of Singa and Site 964 in the Ionian Sea and find several significant differences in the patterns of sapropels in these two locations, which are only several hundred kilometers apart.

Research on the conditions of deposition and on diagenesis of organic carbon-rich sediments in the Mediterranean Sea (Jung et al., 1997; Thomson et al., 1995; van Santvoort et al., 1996) shows that some depositional settings (where sedimentation rates exceed $2 \mathrm{~cm} /$ k.y.) are more favorable for sapropel preservation than others. In addition, sapropels deposited at different locations differ in their geochemical and sedimentological facies as a result of variable depositional conditions. This agrees with work performed in the second area of postcruise studies on Leg 160 materials, which was concerned with studies that shed light on the mechanics of sapropel formation and the variability in the Mediterranean Sea environment. Figure 3 is a schematic representation of some of the hypotheses relating insolation changes and the global climatic evolution to sapropels. Since the onset of sapropel studies, many hypotheses have been formulated that link variable climate and related changes in the hydrology in the Mediterranean catchment to sapropel formation. The hydrological 

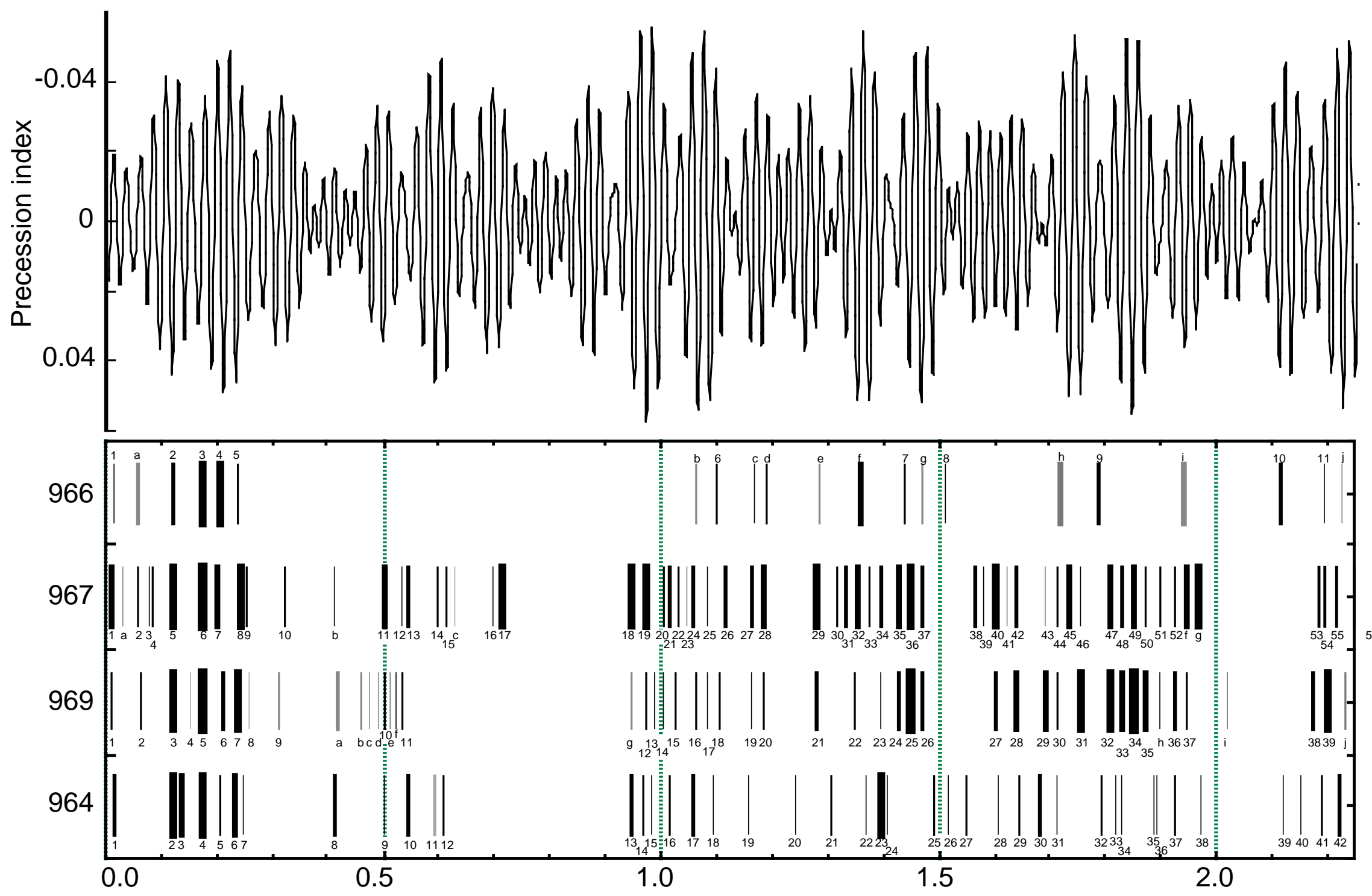

Figure 2. Compilation of sapropel occurrences through time at Sites 964, 969, 967, and 966 for the last 2.25 m.y. The series have been compiled from composite records at each site (Sakamoto et al., Chap. 4 , this volume) and have been tuned to the $65^{\circ} \mathrm{N}$ insolation record (Laskar et al., 1993) aided by stable isotope stratigraphies at Sites 964 and 967 (Howell et al., Chap. 13 , this volume; Kroon et al., Chap. 14, this volume). Gray bars denote sapropel ghosts. Bar width is an indication of sapropel thickness. Labels are site-specific, sequential labels that may differ from traditional sapropel nomenclature. 


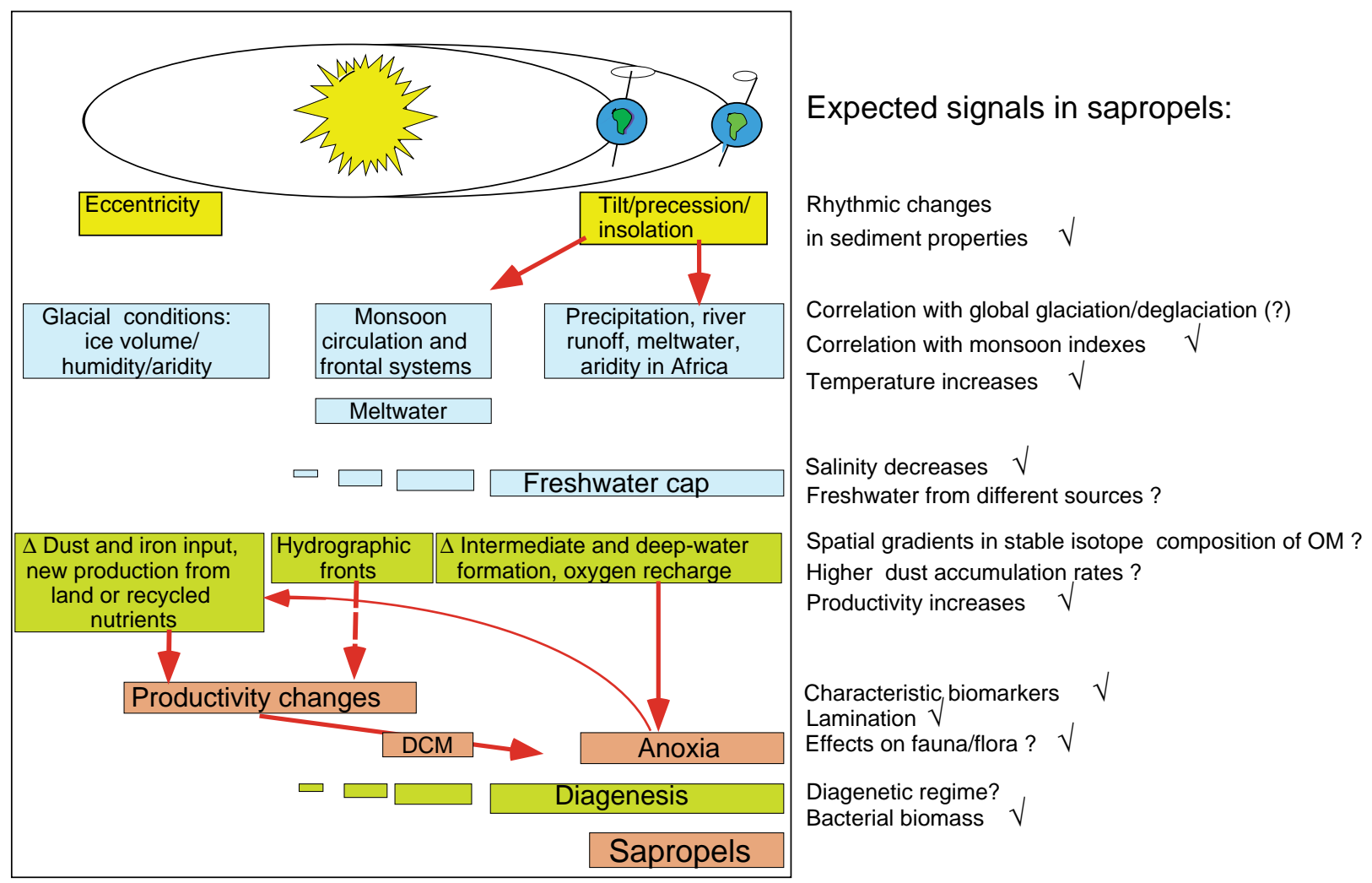

Figure 3. Schematic flow-chart of some of the possible processes leading to sapropel formation and signals that need to be found in sediments to validate the hypotheses. Ticks behind the expected signals denote those which have already been verified.

changes are alternatively thought to be influenced by changes in the water exchange with the North Atlantic Ocean, changes in the moisture transport into the Mediterranean Sea catchment by westerlies, Indian Ocean or African Monsoons, or melt water flooding the Mediterranean Sea during deglaciations. Rohling (1994) gives a comprehensive review of the state of the discussions. The paleoceanographic aims of work after Legs 160 and 161 were to inspect some of the geochemical, mineralogical, and isotopic indicators of the environmental changes associated with sapropel formation. The efforts concerned the long-standing debate over the roles of anoxia and productivity in shaping sapropels, the origin and characteristics of organic matter, indicators of changing ecological patterns, and the use of proxy-indicators for reconstructions of the paleoenvironment in general. In addition, it was attempted to establish high-resolution characteristics of temperature and salinity in surface and conditions in the eolian and riverine catchment of the Eastern Mediterranean. It was hoped that the focussing of multiple approaches on the sapropels would help to shed light on such controversial issues as the role of productivity vs. that of preservation, on anoxia as an agent in the formation of sapropels, and on the origin of fresh water during sapropel formation.

\section{Origin and Significance of Organic Matter in Sapropels}

All evidence gathered on material from Leg 160 supports the hypothesis of anoxic conditions during sapropel formation. First, many sapropels have very high organic carbon concentrations that cannot be explained by productivity alone. Figure 4 is a plot that relates sedimentation rates to organic carbon concentrations and biological productivity in the surface waters. It is based on an empirical relationship published by Müller and Suess (1979). Based on Leg 160 data and actual measurements of bulk density, we find that the sapropels with low $(<10 \%)$ organic carbon concentrations may be comparable to deposits found underneath oceanic upwelling areas (productivities 200-1000 $\mathrm{g} \mathrm{C} \mathrm{m}^{-2} \mathrm{a}^{-1}$ ). Their high-end sedimentation rates bound those of coastal upwelling areas (productivities 200-2000 $\mathrm{gCm}^{-2} \mathrm{a}^{-1}$ ), but in general the sedimentation rates, even of the high-end sapropels, appear to be too low to be upwelling related. When it comes to those sapropels that contain in excess of $10 \%$ (up to $30 \%$ ) organic carbon, we find no marine productivity regime today that produces equivalent masses of organic matter (beyond $5000 \mathrm{~g} \mathrm{C} \mathrm{m}^{-2} \mathrm{a}^{-1}$ ). Modern sediments of anoxic enclosed or semi-enclosed environments such as the Black Sea (Hay et al., 1990) and the Baltic Sea (Emeis et al., in press) contain less than $10 \%$ organic carbon. However, these two possible analogs of the Mediterranean Sea during times of sapropel formation are oligotrophic and have primary production rates of less than $150 \mathrm{~g}$ $\mathrm{C} \mathrm{m}^{-2} \mathrm{a}^{-1}$ (Lassig et al., 1978; Bologa, 1986). The reason for unusually high organic carbon concentrations in sapropels thus appears to be caused by a depositional setting that has no modern analog: elevated productivity paired with anoxic conditions in the water column.

As to the origin of the organic matter, isotopic, molecular, elemental and even microscopic investigations fail to give unambiguous answers, possibly because of the diagenetic overprinting. However, all organic geochemical evidence collected on Leg 160 material suggests that the bulk of organic carbon in sapropels is from marine sources. Land-plant material is consistently present in only subordinate amount (Bouloubassi et al., Chap. 21, this volume; Rullkötter et al., Chap. 22, this volume; Bosch et al., Chap. 23, this volume; Cariou Le Gall et al., Chap. 24, this volume). Bouloubassi et al. studied a set of samples from two groups of sapropels at Site 969: Group 1 was the late Quaternary cluster of S5, S6, and S7, and Group 2 was composed of samples from a sediment interval approximately 2.91- 2.97 Ma. The samples sets differ widely in their organic carbon concentrations, but in general the composition was surprisingly similar: organic mat- 

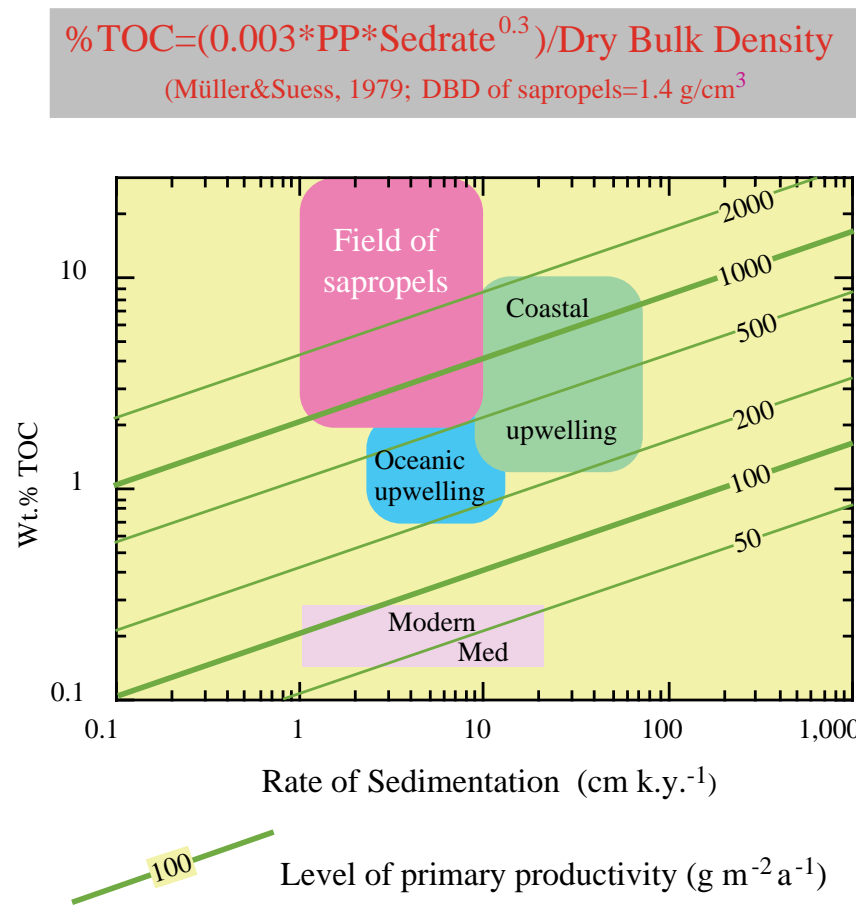

Figure 4. Plot of sedimentation rates and organic carbon concentrations in sediments. Superimposed are isolines representing different levels of surfacewater productivity (calculated according to the procedure by Müller and Suess [1979] based on empirical relationship between productivity (PP), rate of sedimentation (Sedrate), and percent total organic carbon in surface sediments). The fields for the present-day Mediterranean Sea, for coastal upwelling areas and oceanic upwelling areas are marked. Note that the scales are logarithmic and that productivities required for sapropels deposited at sedimentation rates of $1 \mathrm{~cm} / \mathrm{k} . \mathrm{y}$. are unrealistically high. Data from Béthoux (1989) and Morse and Emeis (1992).

ter was found to be dominantly derived from marine algal sources, with variable admixtures of land-derived organic matter. From a positive correlation between organic carbon and long-carbon-chain $n$ alkanes and $n$-alcohols, both of which are considered to be typical terrestrial lipids, Bouloubassi et al. (Chap. 21, this volume) discuss the possibility that sapropel formation may be associated with increased continental runoff. They reject this hypothesis, because they find that nonsapropel samples contain relatively more land-derived organic matter than sapropels when concentrations of indicator molecules are normalized to organic carbon. When organic carbon concentrations and accumulation rates increase, it is mainly from the increased accumulation of marine organic matter.

Rullkötter et al. (Chap. 22, this volume) analyzed the extractable lipids and elemental composition of 39 discrete sapropels sampled from Hole 964D in the Ionian Basin. Organic carbon concentrations of the sapropels vary between 2 and $25 \mathrm{wt} \%$ with a general trend to higher concentrations in sapropels older than 1 Ma. According to their interpretation, the elemental composition with low carbon to sulfur ratios is consistent with a formation under anoxic conditions. High carbon to nitrogen ratios and low hydrogen indexes are interpreted as indications for a considerable microbial reworking of the organic matter in sapropels. Analyses of lipid fractions reveal a predominance of organic matter from marine sources and only small contributions of land-derived material and bacterial sources. Using the average chain length of terrestrially derived $n$-alkanes as an indicator for climatic conditions (temperature and moisture) in the eolian catchment of the eastern Mediterranean Sea and the alkenone unsat- uration ratio $\mathrm{U}_{37}^{\mathrm{k}^{\prime}}$ as a proxy for sea-surface temperatures, Rullkötter and co-workers find a positive correlation between the temperatures on land and in the sea surface. According to their interpretation, the sapropels of Pliocene age have been formed under hotter and wetter conditions than the Pleistocene sapropels. They suggest that increased continental runoff introduced more nutrients, raised productivity, and resulted in deposition of very organic carbon-rich sapropels under anoxic bottom-water conditions.

Sapropel formation under anoxic conditions in the photic zone are indicated for two sapropels of Pliocene age (30 and $8 \mathrm{wt} \%$ organic carbon content) that were analyzed by Bosch et al. (Chap. 23, this volume). They find molecular fossils (characteristic of bacterial chlorophylls) that are specific to green sulfur bacteria. Today, these strictly anaerobic organisms are known from stagnant ponds and lakes and have recently been identified as major primary producers in a deep chlorophyll maximum in the anoxic Black Sea (Repeta et al., 1989). They require the combination of light and $\mathrm{H}_{2} \mathrm{~S}$-containing waters; presence of their biomarkers in sapropels thus supports the concept that a chemocline existed above $\sim 120 \mathrm{~m}$ (the modern depth of the $1 \%$ light level in the Mediterranean Sea), which is the depth that separated oxic surface water and anoxic intermediate water.

A rather stunning new variant of the hypotheses on sapropel formation-formation under oligotrophic conditions in the sea surface and in association stratified conditions in hydrographic frontsemerged from two independent studies. The first investigated the microfabric in an unusual sapropel-containing sequence (from a correlation with nearby holes equivalent to a greatly expanded Sapropel S5) that was deposited in a rapidly subsiding moat surrounding the mud volcano drilled at Site 971 (Pearce et al., Chap. 28, this volume; Kemp et al., Chap. 27, this volume). It is the only sapropel recovered during Leg 160 that contained significant diatom remains and thus must have been shielded from postdepositional opal dissolution. Other laminated sapropels investigated by Kemp et al. (Chap. 27, this volume) only display "remnant" lamination where diatom remains are scarce and where the opal-containing members have been dissolved. The sequence in the moat is rich in diatom mats that form a pronounced sequence of laminations, including possible annual bloom layers. The flora consists of fragile mats of diatoms indicative of stratified, oligotrophic conditions found in association with hydrographic frontal systems. They may create great export production from relatively nutrient-poor waters, because they are adapted to migrate between a nutrient-rich lower water body of the front and a nutrient-poor upper water. Collecting near the interface between upper and lower water mass in the frontal system, the disintegration of slowly grown mats sporadically results in large flux rates of opal and organic matter to the seafloor. The floral assemblage in the diatomaceous sapropel strengthens the hypothesis of fresh water input, which would result in the development of frontal systems in the sea surface. Both microfacies studies provide evidence for anoxic conditions during sapropel formation and both argue that diatoms, even if they are not preserved, are prominent sources for the organic matter in sapropels.

The second argument supporting the hypothesis of oligotrophic conditions during sapropel formation stems from results of Sachs and Repeta (1997) who used a novel technique that measures the stable nitrogen isotope composition of photosynthetic pigments. They find that pigment (original remains of photosynthetic algae from the sea surface) $\delta^{15} \mathrm{~N}$ values remain uniform within and outside sapropel layers, whereas bulk $\delta^{15} \mathrm{~N}$ becomes much lighter within sapropels. Should this be a consistent finding, then it is a clear indication that the light isotope values characteristic of bulk organic matter in sapropels (Calvert et al., 1992) are diagenetic artifacts caused by the abundance of microbial necromass that Cragg et al. (Chap. 25, this volume) find in sapropels. Light nitrogen isotopic signatures and the lack of spatial gradients in the nitrogen isotope composition of coeval sapropels then are not indicators of vastly increased nutrient loads, 
but rather caused by laterally homogeneous organic matter degradation and preferential uptake of isotopically light metabolites in bacteria.

\section{Inorganic Tracers}

What information do sedimentary and chemical tracers carry with regard to the climatic and chemical environment during sapropel formation? Nijenhuis et al. (Chap. 16, this volume) attempt to partition the dominant sources of trace elements by analyzing high-resolution profiles across organic-carbon- and trace element-rich sapropels of Pliocene age (2.94-3.06 Ma) from 3 sites (Sites 967, 966, and 964). The authors find indicators of both high productivity and anoxia in their data and thus support the hypothesis of the Leg 160 shipboard party that both conditions are required for sapropel formation and their subsequent preservation (Emeis et al., 1996). In their budget calculations, Nijenhuis et al. (Chap. 16, this volume) eliminate eolian input, diagenesis, and hydrothermalism as significant sources of tracemetal enrichment. Increased riverine input alone, even when assuming $500 \%$ of modern discharge or dissolved metal loads, cannot account for the observed trace-metal enrichment. The authors thus postulate that the majority of metals originate from sea water, which is stripped of metals (binding to organic matter or as sulfides) when anoxic conditions develop. Their budget calculations lend indirect support for a reversal in circulation during deposition of sapropels, because the metal load deposited over an assumed duration of $6000 \mathrm{yr}$ for each sapropel event would require rapid replacement of stripped water by water advected into the Eastern Mediterranean from the adjacent basin.

The mineralogical and chemical compositions of sapropel-containing sedimentary cycles indicate that changes in the source of detrital matter vary cyclically between eolian and riverine end members. The chemical and mineralogical characteristics permit a differentiation between materials originating from different locations in the eastern Mediterranean catchment. Wehausen and Brumsack (Chap. 17, this volume) analyses two cores from Sites 964 (covering the time interval from 2.87 to $3.0 \mathrm{Ma}$ ) and Site 967 (covering the time span from 2.6 to $2.75 \mathrm{Ma}$ ). In aluminum-normalized element ratios of their high-resolution sample sets, they find rhythmic alternations of eolian and fluvial input that are related to precession-induced climatic variations. All intervals showing maximal fluvial input of detrital matter either culminate in sapropels or in barium enrichments, which the authors interpret as indications for enhanced biological productivity without reaching the sapropel stage. Characteristic chemical compositions indicative of Nile provenance are pronounced in sapropel members in the Eratosthenes Seamount Site 967, whereas the intervening nonsapropel sediments contain material characteristic of modern Saharan or Damascus dust. In Ionian Basin Site 964, the eolian end member is also eolian dust of Sahara origin; the composition of detrital matter deposited during sapropel events is consistent with a source in the northern watershed of the Mediterranean Sea.

A similar pattern of rhythmic changes in the origin of detrital material is seen in clay-mineral analyses of Pliocene sequences at Site 964 and of a corresponding interval from the land sequence of Punta Piccola in southern Sicily (Mélieres et al., Chap. 18, this volume). The age of both intervals is from 2.93 to $3.05 \mathrm{Ma}$ and comprises rhythmic alterations of sapropels and nonsapropels. Mineral assemblages from nonsapropel members are indicative of arid conditions in peri-Saharan areas and a predominantly eolian origin from that area. During these periods of increased eolian transport from the south (dominated by palygorskite, kaolinite, and other minerals), riverine contributions of minerals with northern origin (dominated by smectite and chlorite) decreased. The relationship suggests synchronous decreases in precipitation in the entire watershed of the Mediterranean Sea during the climatic cycles corresponding to precession maxima. During precession minima and sapropel periods, Mélieres et al.
(Chap. 18, this volume) see an increase in riverborne detrital material attributed to increased erosion by water and a decrease in the eolian contribution from the Sahara and the peri-Saharan eolian catchment.

Emeis et al. (Chap. 26, this volume) studied isochronous sapropels from Sites 967 and 964 to reconstruct conditions in surface waters before, during, and after sapropel events. They used alkenone unsaturation ratios as a proxy for sea-surface temperatures and a combination of these temperature estimates and the stable oxygen isotopic composition of surface-dwelling planktonic foraminifers as salinity proxy. Their interpretations are still preliminary, because they rely on open-ocean $\mathrm{U}_{37}^{\mathrm{k}^{\prime}}$-temperature conversion and on an assumption of a constant salinity- $\delta^{18} \mathrm{O}$ relationship during sapropel phases; these two assumption have yet to be verified in the Mediterranean Sea. Average sea-surface temperatures (SST) are high $\left(23^{\circ} \mathrm{C}\right)$ and show little fluctuation in the time interval from 2 to $3 \mathrm{Ma}$ at ODP Site 964 in the Ionian Basin. During this period, no change in the SST was evident across sapropel intervals. Between 0.9 and $1.3 \mathrm{Ma}$, the average temperatures were between $16^{\circ}$ and $21^{\circ} \mathrm{C}$ and varied by as much as $6^{\circ} \mathrm{C}$ within individual sapropel layers. Sapropel SST are markedly higher than those immediately below the organic-rich layers. From $650 \mathrm{ka}$ to the last sapropel of Holocene age, S1, the average SST across sapropels follow the global climatic background and range from as low as $15^{\circ} \mathrm{C}$ (during glacial isotope Stage 6) to $21^{\circ} \mathrm{C}$ (during interglacial isotope Stages 5 and 9), which correspond to a glacial/interglacial temperature change of $6^{\circ} \mathrm{C}$. The ranges of individual SST values are much higher and exceed $10^{\circ} \mathrm{C}$ difference between glacial and interglacial samples. Superimposed on the global glacial/ interglacial temperature pattern is a warming trend of at least $2^{\circ} \mathrm{C}$ at the onset of each sapropel event. Temperature gradients between coeval sapropels from the two basins are less than $2^{\circ} \mathrm{C}$ for the last 400 $\mathrm{ka}$. A decrease in the $\delta^{18} \mathrm{O}$ of planktonic foraminifer calcite by values between $0.7 \%$ and $3.4 \%$ parallels the warming trend in the sequences analyzed by Emeis et al. (Chap. 26, this volume). Of this change from below to within the sapropels, the temperature change explains only a portion of between $0 \%$ and $1.1 \%$ o. Ice-volume changes account for a maximum of $0.32 \%$ from below to within the sapropels.

Under the assumption that salinity and the residual $\delta^{18} \mathrm{O}$ of advected water behave conservatively and using a present-day relationship between the two, the surface-water salinity was lower by as much as 7.7 in Sapropel S4 and usually more than 1 for all other sapropels in the late Pleistocene to Holocene. The data validate the hypothesis that the thermohaline circulation was reduced and that the intermediate- and deep-water formation in the Eastern Mediterranean was weakened or impeded.

\section{WHAT IS STILL OPEN}

Complete sedimentary sequences from a variety of environments and times have been provided by Legs 160 and 161 for study of the sapropel problem, and considerable work has already been undertaken in the short time after the end of Leg 160. Despite the effort, the sapropel knot is still held together by several major tangles. The first concerns stratigraphic aspects. The cyclostratigraphic approach of tuning sapropel stratigraphies offers very attractive means to achieve high-resolution time control. In this method, it is common practice to use sapropel centers as markers of minima in the astronomical precession index with a hard-wired (but empirically based) lag of 3000 yr (Hilgen, 1991; Lourens et al., 1996). This mechanistic assumption carries a potential for an uncertainty for the sapropel ages of several thousands of years and precludes the recognition of time-transgressive processes imbedded in basin dynamics. Any recognizable diachroneity between sites located in different water depths and water masses, or between locations in the different sub-basins, would have implications for the processes acting in the Mediterranean Sea during the transition from nonsapropel to sapropel state. 
The second tangle is the extent of postdepositional alteration and partial or complete eradication of the sediment record during diagenesis. This problem can (to an extent) be circumnavigated by parallel analyses of the same time interval from different holes and sites. During future work, we need to find other sites with "anomalous" sapropels, date them accurately, and determine if they have common properties. In a second step, the nature of changes that occurred in coeval sapropel layers in the vicinity (for example, the "normal" sapropels outside the moat at Site 971; Kemp et al., Chap. 27, this volume) needs to be evaluated based on the evidence from the "anomalous" sapropels to distinguish primary from diagenetic signals in a suite of paleoenvironmental proxies.

\section{ACKNOWLEDGMENTS}

Research on sapropels by K.E. was funded through the Deutsche Forschungsgemeinschaft under Contract Em 37/4 and by the EU (MAS 2-CT 93-0051). T.S. acknowledges funding by the Japanese Society for the Advancement of Science, IOW-contribution number 247.

\section{REFERENCES}

Béthoux, J.-P., 1989. Oxygen consumption, new production, vertical advection and environmental evolution of the Mediterranean Sea. Deep-Sea Res., 36:769-781.

Bologa, A.S., 1986. Planktonic primary productivity of the Black Sea: a review. Thalassia Jugosl., 21/22:1-22.

Calvert, S.E., Nielsen, B., and Fontugne, M.R., 1992. Evidence from nitrogen isotope ratios for enhanced productivity during the formation of eastern Mediterranean sapropels. Nature, 359:223-225.

Emeis, K.-C., Neumann, T., Endler, R., Struck, U., Kunzendorf, H., and Christiansen, C., in press. Geochemical records of sediments in the Gotland Basin-products of sediment dynamics in a not-so-stagnant anoxic basin? Appl. Geochem.

Emeis, K.-C., Robertson, A.H.F., Richter, C., et al., 1996. Proc. ODP, Init. Repts., 160: College Station, TX (Ocean Drilling Program).

Emeis, K.-C., and Shipboard Scientific Party, 1996. Paleoceanography and sapropel introduction. In Emeis, K.-C., Robertson, A.H.F., Richter, C., et al., Proc. ODP, Init. Repts., 160: College Station, TX (Ocean Drilling Program), 21-28.

Hay, B.J., Honjo, S., Kempe, S., Ittekkot, V.A., Degens, E.T., Konuk, T., and Izdar, E., 1990. Interannual variability in particle flux in the southwestern Black Sea. Deep-Sea Res. Part A, 37:911-928.

Hilgen, F.J., 1991. Astronomical calibration of Gauss to Matuyama sapropels in the Mediterranean and implication for the geomagnetic polarity time scale. Earth Planet. Sci. Lett., 104:226-244.

Jung, M., Ilmberger, J., Mangini, A., and Emeis, K.-C., 1997. Why some Mediterranean sapropels survived burndown (and others did not). Mar. Geol., 141:51-60.
Laskar, J., Joutel, F., and Boudin, F., 1993. Orbital, precessional, and insolation quantities for the Earth from $-20 \mathrm{Myr}$ to $+10 \mathrm{Myr}$. Astron. Astrophys., 270:522-533.

Lassig, J., Leppänen, J.M., Niemi, A., and Tamelander, G., 1978. Phytoplankton primary production in the Gulf of Bothnia 1972-1975 as compared with other parts of the Baltic Sea. Finn. Mar. Res., 244:101115.

Lourens, L.J., Antonarakou, A., Hilgen, F.J., Van Hoof, A.A.M., VergnaudGrazzini, C., and Zachariasse, W.J., 1996. Evaluation of the Plio-Pleistocene astronomical timescale. Paleoceanography, 11:391-413.

Morse, J.W., and Emeis, K.-C., 1992. Carbon/sulfur/iron relationships in upwelling sediments. In Summerhayes, C.P., Prell, W.L., and Emeis, K.C. (Eds.), Upwelling Systems: Evolution since the Early Miocene. Geol. Soc. Spec. Publ. London, 64:247-255.

Müller, P.J., and Suess, E., 1979. Productivity, sedimentation rate, and sedimentary organic matter in the oceans, I. Organic carbon preservation. Deep-Sea Res. Part A, 26:1347-1362.

Repeta, D.J., Simpson, D.J., Jørgensen, B.B., and Jannasch, H.W., 1989. Evidence for anoxygenic photosynthesis from the distribution of bacteriochlorophylls in the Black Sea. Nature, 342:69-72.

Rohling, E.J., 1994. Review and new aspects concerning the formation of eastern Mediterranean sapropels. Mar. Geol., 122:1-28.

Sachs, J.D., and Repeta, D.J., 1997. Nitrogen isotopic measurements of chlorophyll suggest Eastern Mediterranean sapropels result from enhanced preservation of organic matter. Proc. Eur. Union Geosci., Terra Nostra, 9:401.

Sakamoto, T., Emeis, K.-C., Kroon, D., Howell, M.W., di Stefano, E., Sprovieri, R., Spezzaferri, S., Staerker, S., and Lourens, L., 1997. The Eastern Mediterranean composite sections from Leg 160. Proc. Eur. Union Geosci., Terra Nostra, 9:400.

Thomson, J., Higgs, N.C., Wilson, T.R.S., Croudace, I.W., De Lange, G.J., and Van Santfoort, P.J.M., 1995. Redistribution and geochemical behavior of redox-sensitive elements around S1, the most recent Eastern Mediterranean sapropel. Geochim. Cosmochim. Acta, 59:3487-3501.

Van Santvoort, P.J.M., de Lange, G.J., Thomson, J., Cussen, H., Wilson, T.R.S., Krom, M.D., and Ströhle, K., 1996. Active post-depositional oxidation of the most recent sapropel (S1) in sediments of the Eastern Mediterranean. Geochim. Cosmochim. Acta., 60:4007-4024.

Vergnaud-Grazzini, C., Ryan, W.B.F., and Cita, M.B., 1977. Stable isotope fractionation, climatic change and episodic stagnation in the Eastern Mediterranean during the Late Quaternary. Mar. Micropaleontol., 2:353370 .

Wüst, G., 1961. Das Bodenwasser und die Vertikalzirkulation des Mittelländischen Meeres. Dtsch. Hydrogr. Z., 14:81-92.

Date of initial receipt: 18 July 1997

Date of acceptance: 31 October 1997

Ms 160SR-058 